\title{
Copyright Application for Students' Work at State Vocational High School 1 Demak Multimedia Majors
}

\author{
Rindia Fanny Kusumaningtyas ${ }^{*}$, Sang Ayu Putu Rahayu ${ }^{2}$, Arif \\ Hidayat $^{3}$ \\ 1,2,3 Faculty of Law, Universitas Negeri Semarang, Indonesia \\ Corresponding Email: rindiafannykusumaningtyas@mail.unnes.ac.id
}

\begin{abstract}
High School (SMK) is one of the educational institutions responsible for creating human resources that have skills so that at the time of graduation can develop performance in the world of work. most vocational school students who take multimedia corner where currently have spawned creative works. The existence of Law Number 28 of 2014 concerning Copyright is very important for the existence of legal protection for the copyrighted works of SMK students in the multimedia field. Because of the importance of understanding copyright and its legal protection. The targets of this activity are students of SMK N 1 Demak majoring in Multimedia, which are expected to develop their potential in finding creative works and knowing their benefits and legal protection. The method used in overcoming problems regarding developing the potential of SMK students in creating creative works. So that SMK students know the legal protection and benefits of copyrighted works and understand things that can be categorized as copyright works, who has the right to be the copyright holder, and what actions can violate Rights in accordance with Law Number 28 of the Year 2014 concerning Copyright. The steps taken to address the issues described above are: (1) Development or socialization of copyright recognition; dan (2) Coaching in developing the potential of vocational school students in creating copyrighted works.
\end{abstract}

Keywords: SMKN 1 Demak Students; Copyright; Multimedia Works; Legal Protection

How to cite:

Kusmaningtyas, R., Rahayu, S. A. P., \& Hidayat, A. (2021). Copyright Application for Students' Work at State Vocational High School 1 Demak Multimedia Majors. Indonesian Journal of Advocacy and Legal Services, 3(1), 13-34. https://doi.org/10.15294/ijals.v3i1.42127 


\section{A. Introduction}

Indonesia is a developing country with a rapidly increasing youth population, judging by data on the growth of 15 - 64 years of age (productive age) of 183.36 million people or $6.51 \%$ of indonesia's total population in 2019 which is projected to reach 266.91 million people. ${ }^{1}$ Indonesia also has a dependency ratio of $45.56 \%$ of indonesia's population which means that every 100 people of productive age (labor force) have dependents of 46 unproductive populations (ages $0-14$ plus the age of 65 and above),,$^{2}$ therefore this productive age population must be provided with adequate life skills. In Indonesia, efforts to improve human resources have long been carried out with various innovations in education and training programs. Education is a fundamental thing that will sustain the progress of a nation. One of the educational media in Indonesia is a formal school built by both the government and private parties as a platform for educators to channel all science materials and information to educated or students. This school was founded with various levels following the growing age of a child in order to be adapted to his content and mindset. Indonesia itself stipulates the compulsory study for 12 years with the last level in High School (SMA) and/or Vocational High School (SMK).

One of the containers that can directly hone students' skills is through Vocational High School (SMK) both SMK Negeri and SMK Swasta. Vocational High School or later called SMK is one of the educational institutions responsible for creating human resources that have the ability, skills, and expertise so that graduates can develop performance in the world of work. ${ }^{3}$ The meaning of this education is spelled out more specifically in Government Regulation No. 29 of 1990 on Secondary Education which mentions vocational secondary education is a secondary education that prioritizes the development of students' abilities for the implementation of certain types of work. SMK is an educational institution that has the potential to prepare human resources that can be absorbed by the world of work, because applicative theory and practice materials have been given since

1 Bappenas, "Data Statistik Kependudukan Kementrian Perencanaan Pembangunan Nasional (Bappenas)," 2018.

2 Katadata, "Jumlah Penduduk Indonesia 2019 Mencapai 267 Juta Jiwa," 2020.

3 Arif Firdausi \& Barnawi, Profil Guru SMK Profesional, Yogyakarta, Ar-Ruz Media, 2011.

14 Indonesian Journal of Advocacy and Legal Services, Vol. 3 No. 1 (2021) 
first entering vocational school, with the hope that smk graduates have the potential according to the needs of the world of work. ${ }^{4}$

SMK itself is developed into various areas of direction that are adapted to the development of the current working area. In this modern era, work related to the digital world is growing rapidly, so it takes human resources that are capable in that. SMK also took its role in the establishment of quality human resources by bringing multimedia majors into its education curriculum. Multimedia comes from 2 words namely Multi and Media, multi means a lot and media means intermediary. The whole multimedia sense means the combination or merging of multiple media such as text, audio, video, animation, and images presented in computer use with the help of tools and links resulting in an interesting presentation. Multimedia according to Robin and Linda is a tool that creates dynamic and interactive presentations that combine graphics, text, animation, video, and audio. ${ }^{5}$ The category in multimedia there are 2 kinds, and that is Multimedia Communication which is the use of media that has the function of publishing information. In this category the media used are TV, radio, movies, games, music, entertaiment, tutorials, internet, and print media. The second category is Multimedia Content Production which is the use of several different media such as text, animation, audio, video, images (graphics) combined to produce multimedia products such as music, games, movies, entertaiment, and others. In the world of education, especially vocational school, multimedia majors are one of the learning media that combines several elements of media presented in computer media. 6

Vocational High School students who take multimedia majors have spawned many of their creative works according to what they have learned in Vocational High School. From this indirectly students with multimedia majors have become creators of his creation and are entitled to the copyright of his work. Copyright under Law No. 28/2014 concerning Copyright has an exclusive definition of the creator's right that arises automatically based on declarative principles after a creation is realized in tangible form without easing restrictions in accordance with the provisions of the legislation. This Law also defines the creator as a person or several people who individually or

4 Dwi Jatmoko, "Relevansi Kurikulum SMK Kompetensi Keahlian Teknik Kendaraan Ringan Terhadap Kebutuhan Dunia Industri Di Kabupaten Sleman.” Jurnal Pendidikan Vokasi, Vol. 3 No. 1, 2013, pp. 1-13.

5 Deni Darmawan, Inovasi Pendidikan: Pendekatan Praktik Teknologi Multimedia Dan Pembelajaran Online, Bandung, PT. Remaja Rosdakarya, 2014, pp. 47-48.

6 Firdausy Armansyah, Sulton Sulton, \& Sulthoni Sulthoni, "Multimedia Interaktif Sebagai Media Visualisasi Dasar-Dasar Animasi.” Jurnal Kajian Teknologi Pendidikan Vol. 2, No. 3, 2019, pp. 225-2226. 
together produce a creation that is distinctive and personal, while the creation is any work created in the field of science, art, and literature produced for inspiration, ability, mind, imagination, dexterity, skill, or skill, expressed in real form. Multimedia technology comes with human creative ideas that are almost difficult to separate first, because the two means support and complement each other. Creative ideas living in a society with copyright have a very close correlation. Creative ideas that are the basis for this creative economy and supported by the rapid growth of technology become one of the mainstays of the nation and the State of Indonesia. basis for the birth of a work of copyright ${ }^{7}$ is no exception for students in Vocational High School multimedia major.

However, in fact, as vocational students who do not have a widely of other knowledge, their work is often misused by an individual and is taken away from the rights that arise from his creation or it could be that the copyrighted work is only made to become material. assessment at school and being left just like that without any development even though it could be that the work has potential in it, without the protection of the copyrighted work it could be that individuals are not responsible for claiming the work of the SMK students then modifying it and using it as a a commercial product for itself without giving rights to the work to the original creator, and multimedia as a product of technology and information development whose media exists in the digital world will be more easily misused without a trace of the perpetrator. Eventhough in Law Number 28 of 2014 concerning Copyright already regulates copyright protection in relation to technological and information developments as stipulated in Articles 54, 55, and 56 of Law Number 28 of 2014 concerning Copyright, in the end it still remains copyrighted works in digital form are indeed very easy to duplicate and the results of these actions are almost indistinguishable from the original. Not only that, people can then make modifications to the copies and distribute them throughout the world at almost no cost. On the one hand, this certainly makes it very easy for almost everyone to violate the copyrights of others on a very large scale, but on the other hand, it is very difficult for copyright owners to detect violations, recognize, or then take legal action. ${ }^{8}$

7 Besar Besar, "Pengaturan Karya Cipta Multimedia Menurut Undang - Undang Nomor 28 Tahun 2014," Online Article, BINUS UNIVERSITY, 2018. https://businesslaw.binus.ac.id/2018/04/02/pengaturan-karya-cipta-multimedia-menurut-undangundang-nomor-28-tahun-2014/

8 Yusran Isnaini, Hak Cipta Dan Tantangannya di Era Cyber Space, Bogor, Ghalia Indonesia, 2009, p. 28. 
Based on what has been described above, it is stated that the work of Vocational High School students with multimedia majors has a large enough potential to become the target of unscrupulous people who abuse it and take the copyright of the students' work. For this reason, it is important for the protection of the copyrighted works of vocational school students in the multimedia field that are adjusted to the provisions of Law Number 28 of 2014 concerning Copyright, so that in the future the creative works of the young successors of this nation can continue to develop their potential without losing their rights. the work of creation for the creator himself.

\section{B. Method}

The method used in overcoming problems regarding developing the potential of vocational school students in creating creative works. So that SMK students know about legal protection and the benefits of copyrighted works that have been created through coaching or socialization of the introduction of Intellectual Property, in particular Copyright as regulated in Law Number 28 of 2014 concerning Copyright. In this guidance or socialization, it also provides an overview of what must be understood regarding what can be categorized as a copyright work, who has the right to be the creator and what actions can violate rights.

The steps taken to address the issues described above are as follows:

1. Development or socialization of copyright recognition; and

2. Coaching in developing the potential of vocational school students in creating copyrighted works.

The working procedures carried out to support the realization of the methods offered are focused on the efforts of understanding Vocational High School students in SMK N 1 Demak Multimedia Majors which is packaged in several stages namely as socialization and continued discussion and question and answer.

\section{Result and Discussion}

\section{Results of Activities}

In this activity the participants or vocational school students majoring in multimedia were very enthusiastic about participating in this Community Service activity. This service aims to provide an understanding to students regarding the importance of knowledge of Copyright and the rights contained in Copyright so that after this activity the participants understand and better understand the importance of knowledge related to Copyright and in order to 
develop the potential of SMK jrusan students. multimedia in creating creative works.

\section{Limitation of Research Program}

\subsection{Definition of Copyright}

Copyright according to Law Number 28 of 2014 is the exclusive right of a creator that is obtained automatically based on the declarative principle after a work is manifested in a tangible form without reducing restrictions in accordance with the provisions of laws and regulations. Copyright protection has a first to announce protection system, where the party who first announces a copyrighted work will get legal protection, and another alternative can use the registration method for the copyright work at the Directorate General of Intellectual Property.

A work that is protected by copyright can be owned by individuals or collectively where a copyright work has specific or personal criteria or can be said to be something new. A creative work itself can be in the field of science, art, and literature which is produced based on inspiration, ability, thought, imagination, dexterity, skill, or expertise that is expressed in a tangible form.

Copyright protection is obtained through an announcement, where anyone can make an announcement that is like being shown or shown. It can also be registered at the Directorate General of Intellectual Property.

\subsection{Definition of Multimedia}

According to Robin and Linda in Darmawan, multimedia is a tool that creates dynamic and interactive presentations that combine graphics, text, animation, video and audio. ${ }^{9}$ Multimedia can be categorized into 2 types, namely linear multimedia and interactive multimedia. Linear multimedia is multimedia that is not equipped with any controller that can be operated by the user. Multimedia is running sequential (sequential / straight), for example: TV and films. Meanwhile, interactive multimedia is multimedia that is equipped with a controller (or assistive devices in the form of a computer, mouse, keyboard, etc.) which can be operated by the user, so that the user can choose what he wants for the next process, for example, such as a game application. Interactive multimedia combines and synergizes all media consisting of text, graphics, audio, and interactivity (design).

9 Firdausy Armansyah, Sulton Sulton, \& Sulthoni Sulthoni, "Multimedia Interaktif Sebagai Media Visualisasi Dasar-Dasar Animasi." Jurnal Kajian Teknologi Pendidikan Vol. 2, No. 3, 2019, p. 227. 
How multimedia presented, there are several presentation methods in multimedia ${ }^{10}$ which include:

1) Paper-based multimedia, for example: books, magazines, brochures.

2) Light-based multimedia, for example: slideshows, transparency.

3) Audi-based Multimedia, for example: CD players, tape recorders, radio.

4) Moving-image-based Multimedia, for example: television, VCR (Video Cassete Recorder, film.

5) Digilatally-Based Multimedia, for example: computers.

\subsection{Multimedia as a Department of Vocational High School Students}

Vocational High School Students (SMK) is an educational institution that has a student program that is required to have expertise. As in SMK in general, SMK has several Expertise Programs, one of which is Wood Craft, Metal Craft, Textile Craft, TK (computer and network engineering), and Multimedia.

Seeing the increasingly competitive world of work, vocational students are required to have expertise. Therefore, the SMK has opened a new department, namely Multimedia. Where students are encouraged to explore and study graphic design through multimedia subjects. In multimedia subjects, SMK students are expected to be able to master graphic design, both in terms of images and techniques. In addition, students must also be able to create a work or graphic design product with various models and shapes, for example graphic design products on the free market, such as business cards, leaflets, CD covers, cassette covers, t-shirt designs, subject book covers, posters and others. ${ }^{11}$

\section{Copyright Protection Implementation for Student}

\subsection{Multimedia as a copyright work protected by Law Number 28 of} 2014

The presence of multimedia has resulted in the emergence of many works that can increase creative ideas and improve the economy both from individuals and countries. Multimedia technology compared to human creative ideas is almost difficult to separate which one is first, because the two tools support and complement each other. The creative ideas that exist in

10 Besar Besar, "Pengaturan Karya Cipta Multimedia Menurut Undang - Undang Nomor 28 Tahun 2014," Online Article, BINUS UNIVERSITY, 2018. https://businesslaw.binus.ac.id/2018/04/02/pengaturan-karya-cipta-multimedia-menurut-undangundang-nomor-28-tahun-2014/

11 Ajeng Maulina, "Pembelajaran Desain Grafis Pada Mata Pelajaran Multimedia Di SMK Negeri 02 Adiwerna Tegal.” Eduarts: Journal of Visual Arts Vol. 3 No. 1, 2014, p. 46. 
copyrighted societies have a very close correlation. The creative idea that is the basis for this creative economy and which is supported by the rapid development of technology has become one of the mainstays of the nation and the State of Indonesia and various countries. ${ }^{12}$

Looking to the copyright is the most important basis for the national economy in the form of creativity, the government has updated the Copyright Law so that it can describe the protection and development of the creative economy, so that protection and development of the Copyright and Related Rights sector can contribute to a more optimal state economy.

Law Number 28 of 2014 concerning Copyright regulates multimedia works. Article 40 of Law Number 28 Year 2014 concerning Copyright regulates the types of Works that are protected including Works in the fields of science, art and literature, consisting of:

1) books, pamphlets, appearance of published papers, and all other written works;

2) lectures, lectures, speeches, and other similar works;

3) teaching aids made for the benefit of education and science;

4) songs and / or music with or without subtitles;

5) drama, musical drama, dance, choreography, puppetry, and pantomime;

6) fine arts in all forms such as paintings, drawings, carvings, calligraphy, sculpture, sculpture or collage;

7) work of applied art;

8) architectural works;

9) map;

10) batik artwork or other motif art;

11) photographic works;

12) Portrait;

13) cinematographic works;

14) translations, interpretations, adaptations, anthologies, databases, adaptations, arrangements, modifications and other works resulting from the transformation;

15) translation, adaptation, arrangement, transformation, or modification of traditional cultural expressions;

16) compilation of Works or data, either in a format that can be read by a computer program and other media;

12 Besar Besar, "Pengaturan Karya Cipta Multimedia Menurut Undang - Undang Nomor 28 Tahun 2014," Online Article, BINUS UNIVERSITY, 2018. https://businesslaw.binus.ac.id/2018/04/02/pengaturan-karya-cipta-multimedia-menurut-undangundang-nomor-28-tahun-2014/ 
17) compilation of traditional cultural expressions as long as the compilation is original;

18) video games; and

19) computer program.

The types of works that cannot be protected are contained in Article 41 of the Copyright Law, which is related to:

1) works that have not been translated into tangible forms;

2) any idea, procedure, system, method, concept, principle, finding or data even though it has been disclosed, stated, described, explained, or combined in a Work; and

3) tools, objects or products that are created solely to solve technical problems or whose form is intended only for functional purposes.

In addition to Article 42 of the Copyright Law Number 28 of 2014, the works that cannot be protected are:

1) results of open meetings of state institutions;

2) laws and regulations;

3) State speech or speech of government officials;

4) court decisions or judge orders;

5) holy book or religious symbol.

In terms of Law Number 28 of 2014 concerning Copyright, multimedia copyright works in the form of:

1) Paper-based multimedia, for example: books, magazines, brochures.

2) Light-based multimedia, for example: slideshows, transparency.

3) Audi-Based Multimedia, for example: CD players, tape recorders, radio.

4) Moving-image-based Multimedia Based on moving images (Movingimage-based), for example: television, VCR (Video Cassete Recorder), film.

5) Digilatally-Based Multimedia, for example: computers.

It can be said that it can be protected by the Copyright Law if the work created has an element of novelty from the previous work.

The government through the Ministry of Education and Culture has issued Government Regulation (PP) No. 29 of 1990 on vocational secondary education. The purpose of vocational education as stipulated in article 3 paragraph 2 states that Vocational High School aims to; (1) entering the workforce and developing a professional attitude, (2) preparing students to be able to choose careers, competent and able to develop themselves, (3) preparing middle-level workers to fill the needs of the business / industrial world at present or in the future. come, and (4) prepare to graduate in order 
to become productive, adaptive and creative citizens. ${ }^{13}$ So that vocational students majoring in multimedia are expected to have a provision of knowledge about law, especially Copyright related to multimedia works that have been produced after graduating from Vocational High School.

Copyright has a very important role, especially in legal protection of works produced by vocational students, including the multimedia department. The function of copyright on a copyright work is to have rights in the form of moral rights and economic rights. A copyright work gets a moral right and an economic right if it has received Copyright protection, where Copyright protection is obtained by being declared / displayed in the public, or by registering a copyright work at the Directorate General of Intellectual Property (Dirjen KI).

Legal protection is a protection given to legal subjects through the prevailing laws and regulations and in its implementation there is a sanction, in the form of legal instruments both preventive and repressive in nature, both written and unwritten. So that legal protection can be called a description of the function of law, namely the concept where law can bring order, certainty, benefit and peace. ${ }^{14}$ According to Gustav Radburch, the essence of value to law is that the law in its attainment cannot be separated from justice, certainty and benefits. ${ }^{15}$ Legal certainty of a copyright work refers to ownership of a work. Not completely regulated for multimedia works that are declared / announced or not by way of recording at the Director General of KI. So it must include something of ownership or name on the work produced such as watermarks in videos, cinematography, or graphic designs, and so on. ${ }^{16}$

Moral Rights and Economic Rights are forms of legal benefit which are regulated in Articles 20-30 of Law Number 28 of 2014 concerning Copyright.

Related rights are exclusive rights which include moral rights of performers, economic rights of performers, economic rights of phonogram producers, and economic rights of broadcasters.

13 Agamuddin Agamuddin, Fahmi Rizal, \& Fera Susanti, "Evaluasi Dan Disain Hipotetik Program Praktek Kerja Industri (Prakerin) Siswa SMK Negeri 2 Padang Panjang." Jurnal Pendidikan Teknologi Kejuruan Vol. 1 No. 1, 2018, pp. 13-14.

14 Siti Hatikasari, "Esensi Perlindungan Hukum Dalam Sistem First To Announce Atas Karya Cipta." Supremasi Hukum: Jurnal Penelitian Hukum Vol. 27 No. 2, 2019, pp122123.

15 Suwardi Sagama,"Analisis Konsep Keadilan, Kepastian Hukum Dan Kemanfaatan Dalam Pengelolaan Lingkungan.” Mazahib Vol. 15 No. 1, 2016, pp. 22-23.

16 Suhono H Supangkat, "Watermarking Sebagai Teknik Penyembunyian Label Hak Cipta Pada Data Digital.” Departemen Teknik Elektro Institut Teknologi Bandung Vol. 6 No. 3, 2000, pp. 26-27. 
1) Performers moral rights is a right inherent in performing actors that cannot be eliminated or cannot be removed for any reason even though the economic rights have been transferred.. Performers' moral rights include the right to :

a) his name is listed as Performer, unless otherwise agreed; and

b) No distortion of the work, mutilation of the work, modification of the work, or other things that are detrimental to one's honor or reputation unless otherwise agreed.

2) Performers' Economic Rights, includes the right to carry out itself, give permission, or prohibit other parties from doing:

a) Broadcasting or communication of Performers' performances;

b) The fixation of the show that hasn't been fixed;

c) Reproduction of the fixation of the performance in any way or form;

d) The distribution of fixations of performances or copies thereof;

e) Rental of the show fixation or copy thereof to the public; and

f) Provision of publicly accessible show fixation.

3) Broadcasting or Communication of Performers' performances does not apply to:

a) Fixation results of performances that have been given permission by Performers; or

b) Broadcasting or re-communication that has been granted permission by the Broadcasting Institution that first obtained a performance permit.

Distribution of fixations of performances or copies thereof does not apply to works of performances that have been fixed, sold or transferred. Anyone can make commercial use of a work in a show without first asking the author's permission by paying a fee to the creator through the collective management agency.

4) The economic rights of phonogram producers, includes the right to carry out itself, give permission, or prohibit other parties from doing:

a) reproduction of the Phonogram in any manner or form;

b) distribution of the original or a copy of the Phonogram;

c) leasing to the public of a copy of the Phonogram; and

d) the provision of phonograms with or without cables which can be accessed by the public.

The distribution of the original Phonogram or a copy thereof does not apply to the Fixation copy of the show that has been sold or which has transferred ownership by Phonogram Producer to another party. Every person exercising economic rights of Phonogram Producer must obtain permission from Phonogram Producer. 
5) Economic rights of broadcasters, includes the right to carry out itself, give permission, or prohibit other parties from doing:

a) Reruns of broadcasts;

b) Broadcast communication;

c) Broadcast fixation; and / or

d) Broadcast fixation doubling

Furthermore, it also emphasized that everyone is prohibited from distributing without permission for commercial purposes of broadcasting content of Broadcasting Institutions. The relevant right holder has the right to receive royalties if his work is re-published and if his work is not shown with the permission of the relevant rights holder, he has the right to file a lawsuit against the party performing the broadcast.

Copyright is attached to moral rights and economic rights. Moral rights are rights that are eternally attached to the Creator for:

a) continue to include or not include his name on the copy in connection with the use of his Work for the public;

b) using his alias or pseudonym;

c) change his work in accordance with the appropriateness of society;

d) change the title and sub-title of the Work; and

e) defend their rights in the event of a work distortion, mutilation of a work, modification of a work, or anything that is detrimental to one's honor or reputation.

Moral rights cannot be transferred as long as the creator is still alive, but the exercise of these rights can be transferred by will or other causes in accordance with the provisions of laws and regulations after the author dies. In the event of a transfer of the exercise of moral rights, the recipient can relinquish or refuse to exercise his rights provided that the release or refusal of the exercise of said rights is stated in writing.

Economic rights are rights to obtain economic benefits or other related rights on a work. According to Copyright Law No. 28/2014, economic rights are regulated in Article 8 and Article 9. Article 8 reads "Economic rights are the exclusive rights of creators or copyright holders to obtain economic benefits for works". Article 9 reads:

1) The creator or copyright holder as meant in Article 8 has the economic right to do so:

a. Publishing of works;

b. Reproduction of creation in all its forms;

c. Translation of works;

d. Dedicating, arranging, or performing the work;

e. Distribution of works or copies thereof; 
f. Creation show;

g. Announcement of work;

h. Communication of creation; and

i. Rental of creation

2) Every person exercising economic rights as intended in paragraph (1) must obtain permission from the Creator or Copyright Holder.

3) Any person without the permission of the Creator or the copyright holder is prohibited from reproducing and / or commercial use of the work.

Economic rights are rights of creators or copyright holders or related rights owners to enjoy their creations. The use of a work must be authorized by the Creator or copyright holder or related rights owner to protect the economic rights and moral rights of a work. ${ }^{17}$ Meanwhile, what is meant by moral rights is a right that protects the personal interest or reputation of an Creator. According to the Copyright Law No. 28 of 2014, relating to moral rights is regulated in Article 5. So that moral rights as privileges are given to creators for their creations to keep their names in every work of their creation. Moral rights will always be attached to the Creator even though economically the copyright of the work has changed hands to another party.

The period of Copyright protection is in Article 58 to Article 61 of Law Number 28 of 2014. For the period of Copyright protection for works:

a. books, pamphlets, and all other written creation that like;

b. lectures, lectures, speeches, and other similar works;

c. teaching aids made for the benefit of education and science;

d. songs or music with or without subtitles;

e. drama, musical drama, dance, choreography, puppetry, and pantomime;

f. fine arts in all forms such as paintings, drawings, carvings, calligraphy, sculpture, sculpture or collage;

g. architectural works;

h. map; and

i. batik artwork or other motif art,

that is, as long as the creator is alive plus 70 years for the creator has died. In the case of a work that is owned by 2 (two) or more people, Copyright protection is valid for the life of the Creator who died at the latest and lasts 70 (seventy) years thereafter.

Copyright Protection for Works that like:

a. photographic works;

b. Portrait;

17 Ayup Suran Ningsih \& Balqis Hediyati Maharani, "Penegakan Hukum Hak Cipta Terhadap Pembajakan Film Secara Daring." Jurnal Meta-Yuridis Vol. 2 No. 1, 2019, pp. 14-15.. 
c. cinematographic works;

d. video games;

e. Computer program;

f. compilation of written works;

g. translations, interpretations, adaptations, anthologies, databases, adaptations, arrangements, modifications and other works resulting from the transformation;

h. translation, adaptation, arrangement, transformation or modification of traditional cultural expressions;

i. compilation of Works or data, either in a format that can be read by a computer program or other media; and

j. compilation of traditional cultural expressions during the compilation are original works,

valid for 50 (fifty) years from the first time the Announcement was made. Copyright protection of works in the form of applied art works for 25 (twenty five) years from the first time the Announcement is made.

Advancing technology in 2020, it's so easy to declare or show a work very quickly and easily through social media. In fact, there are lots of internet media that with one work upload can generate economic value for the creator, such as YouTube where video content creators if there are many subscribers and video viewers, the YouTube channel owner will get adsense and make money from the advertisements posted by the YouTube developer itself data storage media such as zippyshare, where if a work is uploaded when viewed or downloaded by many people, the uploader will get an incentive in the form of money from clickbait advertisements on web storage because the ad clicks on the web must be. In fact there are many ways to develop a website design work that provides free downloads of the files that website visitors are looking for so that many visitors, the web creator can add ad space slots on the web for rent, thus getting economic benefits from the website.

Basically it revolves around wanting to seek financial gain quickly and ignoring the interests of creators and copyright holders.18 There are many and easy ways to get economic value from a copyrighted work so that there are many ways of cheating that can lead to violations of someone else's copyright. Copyright infringement that can violate the moral and economic rights of the creator of a work can be subject to criminal penalties. The copyright infringement is a complaint offense which means that only the creator can complain to the authorities to be able to process it according to

18 Hadny Awaludin Prandika, "Analisa Perlindungan Hak Cipta Di Jaringan Internet Menurut Undang-Undang No 19 Tahun 2002 Tentang Hak Cipta." Lex Privatum Vol. 3 No. 1, 2015, pp. 55-56 
the criminal provisions. The work process is expected to be careful because the copyrighted work to be protected must be a new work (not the same as the existing one) where the level of novelty itself has multiple interpretations between a little novelty (there is little resemblance to the previous work) with a clear novelty (different).

Preventive legal protection is protection provided by the government with the aim of preventing violations before they occur. This is contained in statutory regulations with the intention of preventing a violation and providing signs or limitations in carrying out an obligation. With this regulation, it will provide a basis for the parties concerned to enforce what the law aspires to do. ${ }^{19}$

Provisions for deviation from the regulations stipulated in Copyright can be punished if there is a violation of a copyright protected work. Enforcement of criminal law in the Copyright Law is a form of justice. Criminal elements for irregularities in ownership of a copyright work are contained in Article 112 to Article 118 of Law Number 28 of 2014 concerning Copyright, which are as follows:

\section{Article 112}

Every person who without rights commits the act as referred to in Article 7 paragraph (3) and / or Article 52 for Commercial Use, shall be punished with imprisonment of up to 2 (two) years and / or a maximum fine of Rp.300,000,000.00 (three hundred million rupiah).

\section{Article 113}

(1) Any person who without rights violates economic rights as referred to in Article 9 paragraph (1) letter i for Commercial Use shall be sentenced to imprisonment for a maximum of 1 (one) year and / or a maximum fine of IDR 100,000,000. one hundred million rupiah).

(2) Any person without rights and / or without permission of an Author or Copyright holder violates the economic rights of an Author as referred to in Article 9 paragraph (1) letter c, letter d, letter f, and / or letter $\mathrm{h}$ for Regular Use. Commercials are punished with imprisonment of up to 3 (three) years and / or a maximum fine of $\mathrm{Rp}$. $500,000,000.00$ (five hundred million rupiah).

(3) Any person without rights and / or without permission of the Author or Copyright holder violates the economic rights of the Author as referred to in Article 9 paragraph (1) letter a, letter b, letter e, and / or letter $\mathrm{g}$ for Regular Use. Commercial is sentenced to imprisonment of up to 4 (four) years and / or a maximum fine of Rp1,000,000,000.00 (one billion rupiah).

19 Siti Hatikasari, "Esensi Perlindungan Hukum Dalam Sistem First To Announce Atas Karya Cipta." Supremasi Hukum: Jurnal Penelitian Hukum Vol. 27 No. 2, 2019, p. 123. 
(4) Any person who fulfills the elements as referred to in paragraph

(3) who is committed in the form of piracy, shall be punished with imprisonment for a maximum of 10 (ten) years and / or a maximum fine of Rp.4,000,000,000.00 (four billion rupiahs).

\section{Article 114}

Any person who manages a trading place in all its forms who knowingly and deliberately allows the sale and / or duplication of goods resulting from a violation of Copyright and / or Related Rights at the trade place managed by him as referred to in Article 10, will be subject to a maximum fine of $\mathrm{Rp} 100,000,000,00$ (one hundred million rupiah).

\section{Article 115}

Anyone who without the consent of the person photographed or their heirs makes Commercial Use, Reproduction, Announcement, Distribution, or Communication of Portraits as referred to in Article 12 for the purpose of advertising or advertising for Commercial Use, both in electronic and non-electronic media, shall be punished with a maximum fine of Rp. 500,000,000.00 (five hundred million rupiah)..

\section{Article 116}

(1) Any person who without rights violates economic rights as referred to in Article 23 paragraph (2) letter e for Commercial Use shall be sentenced to imprisonment for a maximum of 1 (one) year and / or a maximum fine of IDR 100,000,000. one hundred million rupiah).

(2) Any person who without right commits a violation of economic rights as referred to in Article 23 paragraph (2) letter a, letter b, and / or letter $\mathrm{f}$, for Commercial Use shall be sentenced to imprisonment of 3 (three) years and / or a maximum fine of Rp. 500,000,000.00 (five hundred million rupiah).

(3) Any person who without rights violates economic rights as referred to in Article 23 paragraph (2) letter c, and / or letter d for Commercial Use shall be sentenced to imprisonment for a maximum of 4 (four) years and / or a fine. a maximum of IDR 1,000,000,000.00 (one billion rupiah).

(4) Any person who fulfills the elements as referred to in paragraph

(3) who is committed in the form of Piracy shall be sentenced to imprisonment for a maximum of 10 (ten) years and / or a maximum fine of Rp.4,000,000,000.00 (four billion rupiah).

\section{Article 117}

(1) Any person who deliberately and without rights violates economic rights as referred to in Article 24 paragraph (2) letter c for Commercial Use shall be sentenced to imprisonment of up to 1 (one) 
year and / or a maximum fine of Rp100. 000,000 (one hundred million rupiah).

(2) Any person who deliberately and without right commits a violation of economic rights as referred to in article 24 paragraph (2) letter a, letter b, and / or letter d for Commercial Use, shall be sentenced to imprisonment for a maximum of 4 (four). years and / or a maximum fine of $\mathrm{Rp} 1,000,000,000.00$ (one billion rupiah).

(3) Any person who fulfills the elements as referred to in paragraph

(2) who is committed in the form of Piracy shall be sentenced to imprisonment for a maximum of 10 (ten) years and / or a maximum fine of Rp.4,000,000,000.00 (four billion rupiah).

\section{Article 118}

(1) Any person who deliberately and without right commits a violation of economic rights as referred to in Article 25 paragraph (2) letter a, letter b, letter c, and / or letter d for Commercial Use, shall be punished with imprisonment of a maximum of 4 (four) years and / or a maximum fine of $\mathrm{Rp} 1,000,000,000.00$ (one billion rupiah).

(2) Any person who fulfills the elements as referred to in Article 25 paragraph (2) letter d who is committed to piracy shall be punished with imprisonment of not more than 10 (ten) years and / or a maximum fine of Rp.4,000,000,000.00 (four billion rupiah).

The provisions of the copyright law have provided legal protection, both preventively and repressively, namely by providing criminal sanctions for violations of the economic rights of the relevant rights owners as regulated in the Copyright Law so that it can be said that preventively the provisions of the copyright law are adequate. however repressively constrained due to the territorial principle. ${ }^{20}$ These efforts can be made by Vocational High School majoring multimedia students as knowledge in work and especially if there are violations of copyright works so that they are expected to avoid these violations.

\subsection{Copyright Registration Procedures Through the Online System}

The online Copyright registration procedure can be via the website link www.dgip.go.id. The DJHKI official website page, online copyright registration or registration is called E-Copyright. This E-Copyright system aims to provide convenience for people who wish to register records of works and related rights products and are easily accessible anytime and anywhere. To be able to access E-Copyright, the public must first have a username and password to log in to this page. The procedure for obtaining the username and

20 Edwita Ristyan, "Perlindungan Hukum Hak Terkait Terhadap Karya Siaran Skysports Yang Dipublikasikan Melalui Situs Internet." Thesis, Universitas Atma Jaya Yogyakarta 2016, p. 8 
password is by first sending a Registration Request Letter attaching a Statement Letter and supporting attached documents to the Directorate General of Intellectual Property c.q. Directorate General of Information Technology. The registration request letter and the statement letter can be downloaded on the E-Copyright page.

If the letter is sent and verified by the online Copyright team, the public will get an official message via email that includes their username and password to be used to enter the E-Copyright registration page. After getting the username and password, the next procedure is as follows.

Enter your username and password on the form provided. Ensure that the information and results of the uploading of administrative requirements and a copy of the sample work entered into the system are correct. Ensure that the selection of the type of work that you wish to register for registration is in accordance with the type of work regulated in the law. One Payment Code is intended for only One Listing of Works and Related Rights Products. Pay attention to the validity period of the Payment Code for a maximum of 2 (two) days, and if it is not paid within 2 (two) days, the Registration of Works and Related Rights Products is considered null and void. ${ }^{21}$

\section{Conclusion}

Coaching and socialization regarding the Copyright Application For Students' Work at State Vocational High School 1 Demak Multimedia Majors is very important because it provides benefits for students of Vocational High School 1 Demak, Multimedia Department regarding knowledge of Law Number 28 of 2014 about Copyright so that with this understanding it can provide provisions while attending Vocational High School or after graduating from Vocational High School in responding to the existence of violations during work and can anticipate the future. The lack of understanding of students of SMK N 1 Demak majoring in multimedia regarding Copyright, where previously without knowing the Copyright Law, students in making a copyright work have not thought carefully about the consequences of the actions to be carried out. Based on the responses and problems faced in this service activity, it is necessary to hold an advanced stage of socialization regarding Copyright registration assistance, procedures for announcing a copyright work, granting permits or licenses and procedures for resolving Copyright disputes in order to increase seriousness in developing

21 Ni Made Asri Mas Lestari, I Made Dedy Priyanto, \& Ni Nyoman Sukerti, "Pengaturan Dan Prosedur Pendaftaran Hak Cipta Berbasis Online." Jurnal Kertha Semaya Vol. 5 No. 2, 2017, pp. 4-5.

30 Indonesian Journal of Advocacy and Legal Services, Vol. 3 No. 1 (2021) 
the potential for making a Copyright works. It is better if for further socialization it is necessary to involve the Directorate General of Intellectual Property, Ministry of Law and Human Rights.

\section{E. Acknowledgments}

Authors express the thankfulness to all parties involved in this community service program, especially for Students at SMKN 1 Demak and all Teachers and supporting staff.

\section{F. Declaration of Conflicting Interests}

The authors state that there is no potential conflict of interest in the research, authorship, and/or publication of this article.

\section{G. Funding}

Universitas Negeri Semarang by Faculty of Law Research and Community Services Grants.

\section{H. Refrences}

Agamuddin, A., Rizal, R., \& Susanti, F. (2018). Evaluasi dan Disain Hipotetik Program Praktek Kerja Industri (Prakerin) Siswa SMK Negeri 2 Padang Panjang. Jurnal Pendidikan Teknologi Kejuruan, 1(1), 13-18. https://doi.org/10.24036/jptk.v1i1.623

Armansyah, F., Sulton, S., \& Sulthoni, S. (2019). Multimedia Interaktif Sebagai Media Visualisasi Dasar-Dasar Animasi. Jurnal Kajian Teknologi Pendidikan, 224-29. https://doi.org/10.17977/um038v2i32019p224.

Bappenas. (2018). "Data Statistik Kependudukan Kementrian Perencanaan Pembangunan Nasional (Bappenas).

Besar, B. (2018). "Pengaturan Karya Cipta Multimedia Menurut Undang Undang Nomor 28 Tahun 2014." Online Article, Binus University, https://business-law.binus.ac.id/2018/04/02/pengaturan-karya-ciptamultimedia-menurut-undang-undang-nomor-28-tahun-2014/

Darmawan, D. (2014). Inovasi Pendidikan: Pendekatan Praktik Teknologi Multimedia Dan Pembelajaran Online. Bandung: PT. Remaja Rosdakarya.

Firdausi, F., Rifai, A., \& Barnawi, B. (2011). Profil Guru SMK Profesional. Yogyakarta: Ar-Ruz Media.

Hatikasari, S. (2019). Esensi Perlindungan Hukum Dalam Sistem First To Announce Atas Karya Cipta. Supremasi Hukum: Jurnal Penelitian 
Hukum, 27(2), 118-132. https://doi.org/10.33369/jsh.27.2.118-132.

Isnaini, Y. (2009). Hak Cipta dan Tantangannya Di Era Cyber Space. Bogor: Ghalia Indonesia.

Jatmoko, D. (2013). Relevansi Kurikulum SMK Kompetensi Keahlian Teknik Kendaraan Ringan Terhadap Kebutuhan Dunia Industri Di Kabupaten Sleman." Jurnal Pendidikan Vokasi 3(1), 1-13. https://doi.org/10.21831/jpv.v3i1.1572.

Katadata. (2020). "Jumlah Penduduk Indonesia 2019 Mencapai 267 Juta Jiwa"

Lestari, N. M. A. M., \& Priyanto, I. M. D., \& Sukerti, N. N. (2017). Pengaturan Dan Prosedur Pendaftaran Hak Cipta Berbasis Online. Jurnal Kertha Semaya, 5(2), 1-6.

Maulina, A. (2014). Pembelajaran Desain Grafis Pada Mata Pelajaran Multimedia Di Smk Negeri 02 Adiwerna Tegal. Eduarts: Journal of Visual Arts 3(1), 45-53.

Ningsih, A. S., \& Maharani, B. H. (2019). Penegakan Hukum Hak Cipta Terhadap Pembajakan Film Secara Daring. Jurnal Meta-Yuridis, 2(1), 13-32. https://doi.org/http://dx.doi.org/10.26877/m-y.v2i1.3440.

Prandika, H. A. (2015). Analisa Perlindungan Hak Cipta Di Jaringan Internet Menurut Undang-Undang No 19 Tahun 2002 Tentang Hak Cipta. Lex Privatum, 3(1), 49-57.

Ristyan, E. (2016). "Perlindungan Hukum Hak Terkait Terhadap Karya Siaran Skysports Yang Dipublikasikan Melalui Situs Internet.” Thesis, Yogyakarta: Universitas Atma Jaya Yogyakarta.

Sagama, S. (2016). Analisis Konsep Keadilan, Kepastian Hukum Dan Kemanfaatan Dalam Pengelolaan Lingkungan. Mazahib, 15(1), 20-41. https://doi.org/10.21093/mj.v15i1.590.

Supangkat, S. H. (2000). Watermarking Sebagai Teknik Penyembunyian Label Hak Cipta Pada Data Digital. Departemen Teknik Elektro Institut Teknologi Bandung, $\quad 6(3) . \quad 1-9$. https://doi.org/10.1016/j.bbabio.2011.05.011.

\section{Legal Documents}

Law Number 11 of 2008 concerning Electronic Information and Transactions. Law of the Republic of Indonesia Number 31 of 2000 concerning Industrial Designs.

Law of the Republic of Indonesia Number 15 of 2001 concerning Trademarks. Law of the Republic of Indonesia Number 28 of 2014 concerning Copyright. Law of the Republic of Indonesia Number 13 of 2016 concerning Patents. 


\section{Quote}

\section{The copyright bargain: a balance between protection for the artist and rights for the consumer}

\section{Robin Gross}

retrieved from https://www.brainyquote.com/topics/copyright-quotes 


\section{ABOUT AUTHORS}

Rindia Fanny Kusumaningtyas, S.H. M.H., is lecturer at Department of Private and Commercial Law, Universitas Negeri Semarang, Indonesia. Some his works have been published, such as Filosofi Kontrak Bagi Hasil Gross Split dari Sudut Pandang Hukum Kontrak (Arena Hukum, 2020), Tinjauan Yuridis Kepastian Hukum Penggunaan Virtual Currency dalam Transaksi Elektronik (Ditinjau dari Undang-Undang Nomor 7 Tahun 2011 tentang Mata Uang) (Jurnal Penelitian Hukum De Jure, 2019), and Perkembangan Hukum Jaminan Fidusia Berkaitan dengan Hak Cipta Sebagai Objek Jaminan Fidusia (Pandecta Research Law Journal, 2016).

Dr. Sang Ayu Putu Rahayu, S.H., M.H., is lecturer at Department of Private and Commercial Law, Universitas Negeri Semarang, Indonesia. She obtained Bachelor Degree from Universitas Udayana Bali, Master and Doctoral Degree from Universitas Airlangga Surabaya. His research interests are concerning oil and gas law, contract law, and mining law.

Arif Hidayat, S.H., M.H., is lecturer at Department of Administrative and Constitutional Law, Universitas Negeri Semarang, Indonesia. Some of his publications such as Politik Hukum Legislasi Sebagai Socio-Equilibrium Di Indonesia (Jurnal Ius Constituendum, 2019) and The Ideal Relationship between Legal Knowledge and Actual Legal Actions in Indonesia (2 ${ }^{\text {nd }}$ ICILS Conference, 2019). 